\title{
Analysis of the factors affecting the implementation of partnership in Engineering Consulting Enterprises
}

\author{
ZHANG Xin Jie ${ }^{1} \quad$ Lu ZHANG $^{2,3}$ \\ ${ }^{1}$ Inner Mongolia University of Science \& Technology,Baotou,Inner Mongolia,China \\ ${ }^{2}$ Inner Mongolia University of Science \& Technology,Baotou,Inner Mongolia,China. \\ ${ }^{3}$ Civil air defense construction quality supervision station of the city of Baotou,Inner Mongolia,China.
}

KEYWORD: The principal component analysis;Influence factors;Partnership;Chinese Engineering Consulting Enterprises

ABSTRACT: Partnership is the commonly used form of foreign consulting company. In this paper, through literature research, 25 factors that impact the implementation of partnership in China were been summarized. Then based on the questionnaire survey,and using the method of principal component analysis, five critical factors had been grouped. These are namely, the structure of partnership, national and industry policy for partnership implement, the adaptability of the partnership culture, enterprise system innovation, and partnership cognition by community. Then the study provides insights into the five clusters.

\section{Introduction}

Engineering consulting (EC) services cover all areas of national economy and social development, it plays an important role in promoting sustainable development of Socio-economic, its level of development reflects the country's economic and social matureness lever. As a high intelligence service, China EC has a significant gap with international EC, and the EC company's organization form which been impacted by the planned economic system, is impeded the development of China EC industry seriously.Partnership has the advantages of enhance consultants' practical risks, produce a good incentive effects, and integrate partner's resources, etc. This form of organization is particularly suitable for ECF since it is characterized by intensive intelligence. With the development of market economy and the expansion of business scale, China ECF should follow the path of partnership.In 2000, the Ministry of Construction has promulgated the "the notice about Reorganization between construction cost consulting agency and government departments", whose aim is to promote the organization form of ECF in order to adapt to the market development better.However, the partnership has not been popularized in China engineering consulting industry. In response, many researchers have done a lot of meaningful research, and this study is to explore the critical factor which impact the implementation of partnership in China ECF based on other's researches. So as to provide countermeasures and suggestions for enterprise reform in China engineering consulting industry.

\section{Procedures for identifying the impact factors}

State laws and policies play an important role in enterprise reform.First, the China engineering consulting industry doesn't have the Professional Liability Insurance for partners to transfer highrisk which is brought by partnership inherently. Secondly, be short of Personal Property Registration System and Property Division System make it difficult to assume the unlimited liability and joint liability by the partners, leading to the risk constraint of partnership mere formality .Again, in accordance with international practice, the consulting industry is managed by specialized professional associations, government's administration rarely involved, however, China Engineering Consulting Association is inability to manage China engineering consulting industry, this hinder the development of China engineering consulting industry .From the cultural perspective, Wang Dihua pointed out that traditional Chinese culture is one of the important reasons which hindered the implementation of partnership.Partnership organizations need the appropriate corporate culture, it's important spiritual and material resources of the organization, following the 
human, material, financial and information resources after the fifth. Bases on the presented discussions, this paper summarizes 25 factors that impact China ECF to carry out partnership. The results are shown in Table1.

Table 1. Selected factors for implement of partnership in China ECF

\begin{tabular}{|c|c|}
\hline code & factors \\
\hline 1. & To bear unlimited and joint liability \\
\hline 2. & Polities and regulations are incomplete \\
\hline 3 & Partnership in the loss of corporate control \\
\hline 4. & $\begin{array}{l}\text { Slow development of China Engineering } \\
\text { Consulting Association } \\
\text { Integration of partnership culture and Chinese } \\
\text { traditional culture }\end{array}$ \\
\hline 6 & Personal property reporting system is flawed \\
\hline 7. & $\begin{array}{l}\text { Employees' psychological adaptation after the } \\
\text { reform }\end{array}$ \\
\hline 8 & Partnership agreement's operational difficulty \\
\hline 9. & $\begin{array}{l}\text { Partnership can not issue stocks and bonds, } \\
\text { enterprises will face growing crisis }\end{array}$ \\
\hline 10. & Be short of partners to meet the requirements \\
\hline 11. & Partnership with low social acceptance \\
\hline 12. & $\begin{array}{l}\text { Doesn't have professional liability insurance } \\
\text { system }\end{array}$ \\
\hline 13. & $\begin{array}{l}\text { Lack of implementation experience of partnership } \\
\text { in ECF } \\
\text { Be short of exchange of experience with the } \\
\text { international partnership ECF }\end{array}$ \\
\hline 15 & Enterprise Reform under powered \\
\hline 16 & $\begin{array}{l}\text { Partners to fulfill the obligation of mutual } \\
\text { supervision in difficulty }\end{array}$ \\
\hline 17 & $\begin{array}{l}\text { Each partner's economic behavior in behalf of the } \\
\text { partnership binding on all the partners, prone to } \\
\text { disputes between the partners. } \\
\text { Ppartnership culture attach importance to }\end{array}$ \\
\hline 18 & $\begin{array}{l}\text { cooperation, prone to influenced by the individual } \\
\text { circumstances }\end{array}$ \\
\hline 19 & $\begin{array}{l}\text { It is difficult to transfer the ownership of } \\
\text { partnership }\end{array}$ \\
\hline 20 & Financing in the name of partnership firm is hard \\
\hline 21 & $\begin{array}{l}\text { Restructuring of Institutions or the state-owned } \\
\text { assets is lack of state policy support }\end{array}$ \\
\hline 22 & $\begin{array}{l}\text { Reasonable profits distribution between the } \\
\text { partners is difficult }\end{array}$ \\
\hline 23 & Complex process of admitting new members. \\
\hline 25 & $\begin{array}{l}\text { Enterprises don't have legal personality status, so } \\
\text { it's inconvenience in operation } \\
\text { Partner co-operation, may lead to delays in making } \\
\text { decisions }\end{array}$ \\
\hline
\end{tabular}




\section{Research Methods}

As listed in Table 1, all of the 25 factors have an impact on the implementation of partnership in China ECF, there is a difference in terms of importance among the individual factors, and the various factors may be relevant. In order to have a comprehensiveness, suitability, and clarity view of the problem, a survey was conducted to determine the importance of the factors listed in Table 1. In addition, this paper will analyze the data using principal component analysis based on multivariate statistical analysis, then extracted the critical factors impact the partnership implementation in China ECF from the factors listed in Table 1.

At this stage, by feeding the survey results into SPSS17.0, Principal Component Analysis be used to identify a smaller set of uncorrelated factors, which can be used to represent relationships among 25 variables.

By examining the variables with a larger correlation coefficient, analysis the meaning of each factor, critical factors are summarized as follows:the structure of partnership,the national and industry policy for partnership implement,the adaptability of the partnership culture,the enterprise reform innovation and partnership cognition by community.

\section{Discussion}

The statistical analysis in the previous section has led to identification of five critical factors, which affect the implementation of partnership in China ECF significantly.

\section{Principal component 1 : the structure of partnership}

The research reveals that the first critical factor for the implementation of partnership in China ECF is the structure of partnership. Actually, engineering consulting is a intelligence-intensive industry, so the spirit of cooperation of the partners is much more important than the other things. Under partnership, it can give full play of the incentive mechanism, attract more talent for the enterprise, and increase the core competitiveness of the enterprise. In addition, results of the engineering consulting work have a major impact on people's lives the country's economy, accordingly, engineering consultants are bound to work with unlimited liability and joint liability under partnership. As a consequence, the result of the work will be better, the enterprise will be more competitive because of its good reputation.

The structure of partnership is more flexible since the new partnership enterprise law was promulgate. The new law allows legal to take part in partnership, moreover, the special general partnership and limited partnership form are added to the law. A special general partner is no long have the unlimited liability for the losses by the other individual factors, and a limited partner in the partnership only undertake limited liability.This allows companies to choose the form of partnership freely, so as to avoid the unlimited liability legally.

\section{Principal component 2: national and industry policy for partnership implement}

National and industry policy environment is the second critical factor that affecting the engineering consulting companies to implement partnership. National laws are the basis of the implementation of partnership. The state should establish a sound legal policy environment when advocated reform vigorously. Therefore, the State should play a more specific role in the reform.

Additionally, many respondents pointed out that China Engineering Consulting Association doesn't have capacity and power to perform its functions, has generated a serious obstacle to the development of the engineering consulting industry. Since 1992, , after nearly 20 years of development, China Engineering Consulting Association have made great progress, but its capacity still can not meet requirements of the current engineering consulting industry, China Engineering Consulting Association should establish a marketing system as soon as possible.

\section{Principal component 3: the adaptability of the partnership culture}

As the third critical factor that impact the implementation of partnership in China ECF is the adaptability of the partnership culture. Through the investigation we found that many respondents are concerns about partnership culture. They believe that the cooperation of the partners required by partnership is difficult to achieve in China. In fact, it is indicated by many studies that the 
traditional moral in China has a good cultural foundation for the implementation of the partnership. Trying to dig out the corporate culture from the traditional culture is meaningful in practice.

\section{Principal component 4: Enterprise System Innovation}

Be short of the power of enterprise reform and innovation in engineering consulting firm is the fourth critical factor that affect the implementation of partnership. Most of China ECF were established under the planned economy system, rely on state support for many years, so employees may face a great spiritual pressure when the firm completely separate from government departments or institutions. They require a process of adaptation to face the marketing operation mechanisms positively. Nevertheless, enterprise reform is inevitable with the improvement of socialist market economic system.

Guidance for enterprise reform according to local conditions should form a diversified pattern , improve the governance structure, and achieve higher levels of development, so as to face challenge positively.

\section{Principal component 5: partnership cognition by community}

Impact the implementation of partnership in China ECF as the fifth critical factor is the partnership cognition by community. In the survey we found that many engineering consulting practitioners are not familiar with the partnership, the first enterprise organization they thought in the reform is corporate, social awareness of partnership is very low. There is very a few firms have implemented partnership. Therefore, the government should universal the knowledge of partnership when the partnership is encouraged. Strengthen the cooperation with foreign partnership consulting firms, learn their advanced experience should also be done. The government can also set up partnership consulting firm model to enhance understanding and confidence of the partnership by the society.

\section{Conclusion}

Government should play a more specific role in the engineering consulting firm innovation and speed up the process of reorganization. A sound background environment should also be established.As the main system of reform, the consulting firm should enhance understanding of partnership and respond to the challenges of the market economy actively. With the market economy improving and the exchanges with the international engineering consulting firms increasing, partnership will have a gradual development in China.

\section{Acknowledgments}

This work was financially supported by the Innovation Foundation of Inner Mongolia University of Science and Technology(2014QDW013), Research on the PSO-LSSVR Predication Model of Urban Housing Prices.

\section{REFERENCES}

[1] Crane, F. G..Insurance Principles and Practices. 2nded[M]. New York: Wiley, 1984.

[2] Organ D. W..Organizational citizenship behavior: The good soldier syndrome [M]. Lexington, MA: Lexington Books, 1988.

[3] Borch K. Equilibrium in a reinsurance market [J]. Econometric, 1962, 30: 424-444.

[4] Brief.A.P, Motowidlio, S. J. Prosodies organizational behavior, Academy of Management Review, 1986.

[5] Engineering Consulting Industry Development Plan 2010-2015. 